\title{
Management of patellofemoral joint osteoarthritis using biomechanical device therapy: a systematic review with meta- analysis
}

\author{
Michael J. Callaghan ${ }^{1,2,3^{*}}$ (D), Elizabeth Palmer ${ }^{4}$ and Terence O'Neill ${ }^{3,5,6}$
}

\begin{abstract}
Background: Current clinical guidelines recommend conservative management including non-pharmacologic therapy prior to considering surgery for knee OA. There is a paucity of clinical trials investigating the use of biomechanical device therapies on those with patellofemoral joint osteoarthritis (PFJOA). The aim was to systematically review the effectiveness of biomechanical devices (bracing, taping, and footwear) in the management of symptomatic PFJOA.

Method: The Cochrane, PEDro, MEDLINE, CINAHL, AMED and EMBASE electronic databases were search from inception to October 31, 2020. Included studies were randomised controlled or clinical trials studying any form of biomechanical device therapy in the management of PFJOA in the English language. Studies included in the search were quality-appraised using the PEDro scoring system.

Result: Eleven studies were identified which included assessment of either patellar taping, or foot orthotics, knee bracing or combined physiotherapy treatments. Trial quality ranged from 'poor' through 'fair' to 'good'. For patellar bracing, pooled analysis of two good quality randomised controlled trials showed no overall significant improvement on a visual analogue scale (VAS) (random effects (RE) standardised mean difference (SMD) $=-0.42$ $(95 \% \mathrm{Cl}-1.12$ to +0.29$)$.

Pooled data from the same two studies showed a non-significant improvement in favour of bracing assessed by the KOOS/WOMAC (RE SMD $=-0.18(95 \% \mathrm{Cl}-0.66$ to +0.31$)$. Two studies of 'fair' and 'good' quality applying patellar tape showed a significant reduction in pain immediately after application and after 4 days. A randomised trial of a foot orthotic showed a non-significant improvement in pain after 6 weeks with a between groups adjusted mean difference for maximum VAS of $21.9 \mathrm{~mm}(95 \% \mathrm{Cl}-2.1$ to 46.0$)$ and 8.1 ( $95 \% \mathrm{Cl}-6.9$ to 23.1$)$ for KOOS pain. A multimodal physiotherapy intervention (which included taping in two studies) showed a pooled significant improvement in VAS (SMD $=-0.4 ;(95 \% \mathrm{Cl}-0.71$ to -0.09$)$ at 3 months compared to controls.
\end{abstract}

\footnotetext{
* Correspondence: michael.callaghan@mmu.ac.uk

${ }^{1}$ Faculty of Health and Education, Department of Health Professions,

Manchester Metropolitan University, Manchester, UK

${ }^{2}$ Manchester University NHS Foundation Trust, Manchester, UK

Full list of author information is available at the end of the article
}

C C The Author(s). 2021 Open Access This article is licensed under a Creative Commons Attribution 4.0 International License, which permits use, sharing, adaptation, distribution and reproduction in any medium or format, as long as you give appropriate credit to the original author(s) and the source, provide a link to the Creative Commons licence, and indicate if changes were made. The images or other third party material in this article are included in the article's Creative Commons licence, unless indicated otherwise in a credit line to the material. If material is not included in the article's Creative Commons licence and your intended use is not permitted by statutory regulation or exceeds the permitted use, you will need to obtain permission directly from the copyright holder. To view a copy of this licence, visit http://creativecommons.org/licenses/by/4.0/ The Creative Commons Public Domain Dedication waiver (http://creativecommons.org/publicdomain/zero/1.0/) applies to the data made available in this article, unless otherwise stated in a credit line to the data. 
Conclusion: There is some good quality evidence that a combined physiotherapy approach significantly reduces short-term pain in those with PFJOA. Long-term effects of all interventions are still unknown, which indicates the need for further research to determine the longer term impact of all biomechanical devices on outcomes in symptomatic PFJOA.

\section{Background}

The patellofemoral joint (PFJ) is an important source of symptoms in knee osteoarthritis (OA) compared to the tibiofemoral joint (TFJ). In symptomatic knee OA cohorts, the prevalence of radiographic PFJOA is $57 \%$ and in radiographic and symptomatic knee OA cohorts the prevalence of PFJOA is 43\% [1]. Typical features of PFJOA are anterior knee pain or retro-patella pain aggravated with PFJ loading activities such as stair ambulation, squatting, kneeling or rising from sitting. PFJOA symptom management by conservative treatment is critical [2]. Altered mechanics and increased PFJ stress are thought to be involved in the progression of PFJOA [3]. Therefore, patellar bracing and patellar taping (in which medical or sports tape is applied either onto or around the patella) have been suggested as interventions which alter patella position in the trochlea, reduce PFJ stress and limit structural damage [4]. Bracing has the advantage of being easier to self-apply than taping without loosening [5].

Current guidelines in the UK, Europe and America recommend surgery for knee OA only after conservative management including pharmacologic and nonpharmacologic therapy has been exhausted [6-9]. Biomechanical device therapy, which includes taping, bracing and modified footwear with orthotics, insoles or inserts, is appealing as it is not linked with any of the systemic adverse effects associated with pharmacological therapy. There are a paucity of clinical trials to support or refute the use of various biomechanical device therapies for the management of PFJOA with a greater number of clinical trials and systematic reviews focused on TFJ OA [10]. Such data are important to inform optimum clinical practice for this large, symptomatic patient subgroup. An international consensus statement on PFJOA produced a narrative review which implied further need to evaluate treatment outcomes in people with PFJOA [11]. Our aim was to undertake a systematic review with meta-analysis of the efficacy of biomechanical device therapies in the management of PFJOA.

\section{Methods}

\section{Search strategy}

The MEDLINE, AMED, EMBASE, CINAHL and Cochrane Database of Systematic Reviews electronic bibliographic databases were searched from inception to October 31, 2020. The search strategy and search terms are presented in the supplementary file. Search terms were adapted to the requirements of each specific database. Where the full text was obtained, reference lists were searched. Inclusion criteria were English language, peer reviewed, original research, randomised controlled or clinical trials studying biomechanical device therapy (brace, taping and modified footwear including shoe inserts, insoles or foot orthotics) in the management of PFJOA, with validated outcome measures. Exclusion criteria included studies where subjects did not have predominant PFJOA, systematic and narrative reviews, clinical commentaries, editorials or studies from nonpeer reviewed journals. Reference lists of the full-text articles were also checked to ensure any articles not captured in the electronic search were included. We searched the grey literature guided by the 'Grey Matters' checklist (Grey Matters: a practical tool for searching health-related grey literature (https://www.cadth.ca/ resources/finding-evidence). The grey literature search included a search of clinical trial registries (Cochrane Central Register of Controlled Trials with ClinicalTrials. gov) Google Scholar, and forward searches of SCOPUS/ Web of Science for all included articles as well as searching of the reference lists of included articles and related systematic reviews.

\section{Assessment of study quality}

One author (EP) initially independently checked the titles and abstracts of the articles against the inclusion and exclusion criteria. Non-eligible studies were excluded. The methodological quality of full texts was independently assessed by two authors (EP and MJC) using the Physiotherapy Evidence Database critical appraisal tool (PEDro http://www.pedro.org.au). Trials were awarded one point if each criterion was clearly satisfied. Criterion 1 was not included in the final PEDro score, so each study had a possible maximum score of 10. We considered total PEDro scores of $0-3$ as 'poor', 4-5 as 'fair', 6-8 as 'good', and 9-10 as 'excellent' [12]. Any discrepancies in the appraisal scores were resolved by discussion and consensus, after which an agreed score was allocated (Table 1).

\section{Data extraction}

The study design, sample size, exclusion and inclusion criteria, participant characteristics including age, BMI and sex were extracted from the studies. Data extracted 
Table 1 Summary of the PEDro appraisal criteria for all none studies

\begin{tabular}{|c|c|c|c|c|c|c|c|c|c|c|c|c|}
\hline \multicolumn{13}{|c|}{ PEDRO criteria } \\
\hline Studies & 1 & 2 & 3 & 4 & 5 & 6 & 7 & 8 & 9 & 10 & 11 & PEDro Score \\
\hline [13] & $x$ & $x$ & $x$ & $x$ & & & $x$ & $x$ & $x$ & $x$ & $x$ & 8 \\
\hline [14] & $x$ & $x$ & $x$ & $x$ & & & $x$ & $x$ & & $x$ & $x$ & 7 \\
\hline [15] & $x$ & $x$ & $x$ & $x$ & & & & $x$ & & $x$ & $x$ & 6 \\
\hline [16] & $x$ & $x$ & & $x$ & & & $x$ & & $x$ & $x$ & $x$ & 6 \\
\hline [17] & $x$ & $x$ & & $x$ & $x$ & & $x$ & $x$ & $x$ & $x$ & $x$ & 8 \\
\hline [18] & $x$ & $x$ & & & & & $x$ & $x$ & & $X$ & $X$ & 6 \\
\hline [19] & $x$ & $x$ & $x$ & $x$ & $x$ & & $x$ & & $x$ & $x$ & $x$ & 8 \\
\hline [20] & $x$ & $x$ & & & & & & $x$ & & & & 2 \\
\hline [21] & $x$ & $x$ & $x$ & $x$ & & & $x$ & $x$ & $x$ & $x$ & $x$ & 8 \\
\hline [22] & $x$ & $x$ & $x$ & $x$ & & & $x$ & $x$ & $x$ & $x$ & $x$ & 8 \\
\hline [23] & $x$ & $x$ & $x$ & $x$ & & & $x$ & $x$ & $x$ & $x$ & $x$ & 8 \\
\hline
\end{tabular}

Key: $X:$ point awarded when a PEDro criterion was clearly satisfied. Note item 1 (eligibility criterion) is not included in the overall PEDro score The number corresponds to the following PEDro criteria: 1=Eligibility criteria stated, 2=Random allocation, $3=$ Concealed allocation, $4=$ Baseline comparability, $5=$ Blinded subjects, $6=$ Blinded therapists, $7=$ Blinded assessors, $8=$ at least $85 \%$ follow-up, $9=$ =Intention-to-treat analysis, $10=$ Between group statistical analysis, 11=Point measures and measures of variability

to measure the effect of the devices were from visual analog scales (VAS) and numerical rating scales (NRS), specific outcome tools (KOOS, WOMAC), the perceived global rating of change (GRoC), and biomechanical data from knee joint position and muscle strength. Additionally, details on the type and frequency of intervention, comparators and outcomes were collected and recorded by one author (EP) and checked independently by a second (MJC).

\section{Statistical analysis}

For each analysis, statistical heterogeneity was evaluated using the inconsistency value $\left(I^{2}\right)$. An $\mathrm{I}^{2}$ of $75 \%$ and above was interpreted as high heterogeneity [24]. A random-effects meta-analysis was adopted for all continuous data outcomes. All analyses were conducted using RevMan v.5.3.5 software (The Nordic Cochrane Centre, The Cochrane Collaboration, (2020) www. revman.cochrane.org).

\section{Results}

\section{Search results}

The combined search from all of the databases produced 167 articles and following removal of duplicates and conference abstracts, 115 articles remained. 99 articles were discarded based on the title or the abstract alone. From the remaining 16 full texts, another five articles were excluded. Two were excluded as the participants were not randomly allocated to a brace condition [5, 25], two others because the participants either did not have
PFJOA [26], or had TFJOA rather than PFJOA [27, 28]. There were no additional articles found from the reference list of the full-text articles (see Fig. 1).

\section{Methodological quality of the included studies}

A total of eleven randomised clinical trials were assessed for methodological quality. The PEDro scores are detailed in Table 1. Nine studies were classed as 'good' quality, one was classed as 'fair' quality, and one was classed as 'poor' quality.

\section{Study characteristics}

The eleven randomised clinical trials had a total of 658 knees with predominant or isolated symptomatic PFJOA. Two studies ([14] $(n=30)[15] ;(n=106))$ assessed some of the participants from a parent trial $([13], n=126)$. Tan et al. [23] was a biomechanical study nested within a pilot RCT [22]. Two studies did not provide information on the sex of the participants (Kumar \& Ganesh 2011 [20];), so excluding these, the overall percentage of females (62\%) was greater than males though there was wide variation in the proportion of males and females between the studies (males 14-45\% and females 55$86 \%$ ). The mean age of participants was 53 years (range $55-70$ years), and the mean BMI was $28.9 \mathrm{~kg} / \mathrm{m}^{2}$ (range $27.6-31 \mathrm{~kg} / \mathrm{m}^{2}$ ), with one study not providing participants' ages [20]. Radiographic knee OA was assessed and described in eight studies all of which used axial (skyline) plain radiographs as a means of identifying participants with either isolated PFJOA or OA that was more severe in the PFJ than the TFJ. Three studies [1315] included subjects with Kellgren and Lawrence (K-L) scores of grade 2 or 3 in the PFJ, which was greater than the K-L grade for the TFJ, and excluded those whose K$\mathrm{L}$ grade was greater in the TFJ. Those with K-L scores equal in all compartments were included if the signs and symptoms were predominantly in the PFJOA. Two studies $[16,17]$ used the disease severity based on the Osteoarthritis Research Society International (OARSI) Atlas for Radioanatomic Positioning of the Knee. Both studies included radiographic evidence of either an osteophyte of severity grade equal to or greater than 2, or joint space narrowing (JSN) of 1 with concurrent grade 1 osteophyte(s), in the PFJ on skyline radiograph. They excluded individuals with medial more than lateral PFJ osteophytes or with a K-L grade greater than 2 in the TFJ. Quilty et al. [21] included those with K-L grading grade 3 or with greater osteophytes in the PFJ and the absence of K-L grade 3 or 4 TFJ involvement. [19] used the OARSI atlas to assess JSN and osteophytes. PFJOA was defined as an osteophyte or JSN of grade 2 or greater. Those with concomitant TFJOA were not excluded if symptoms were predominantly PFJOA. Cushnaghan et al. [18] had participants with radiographic 


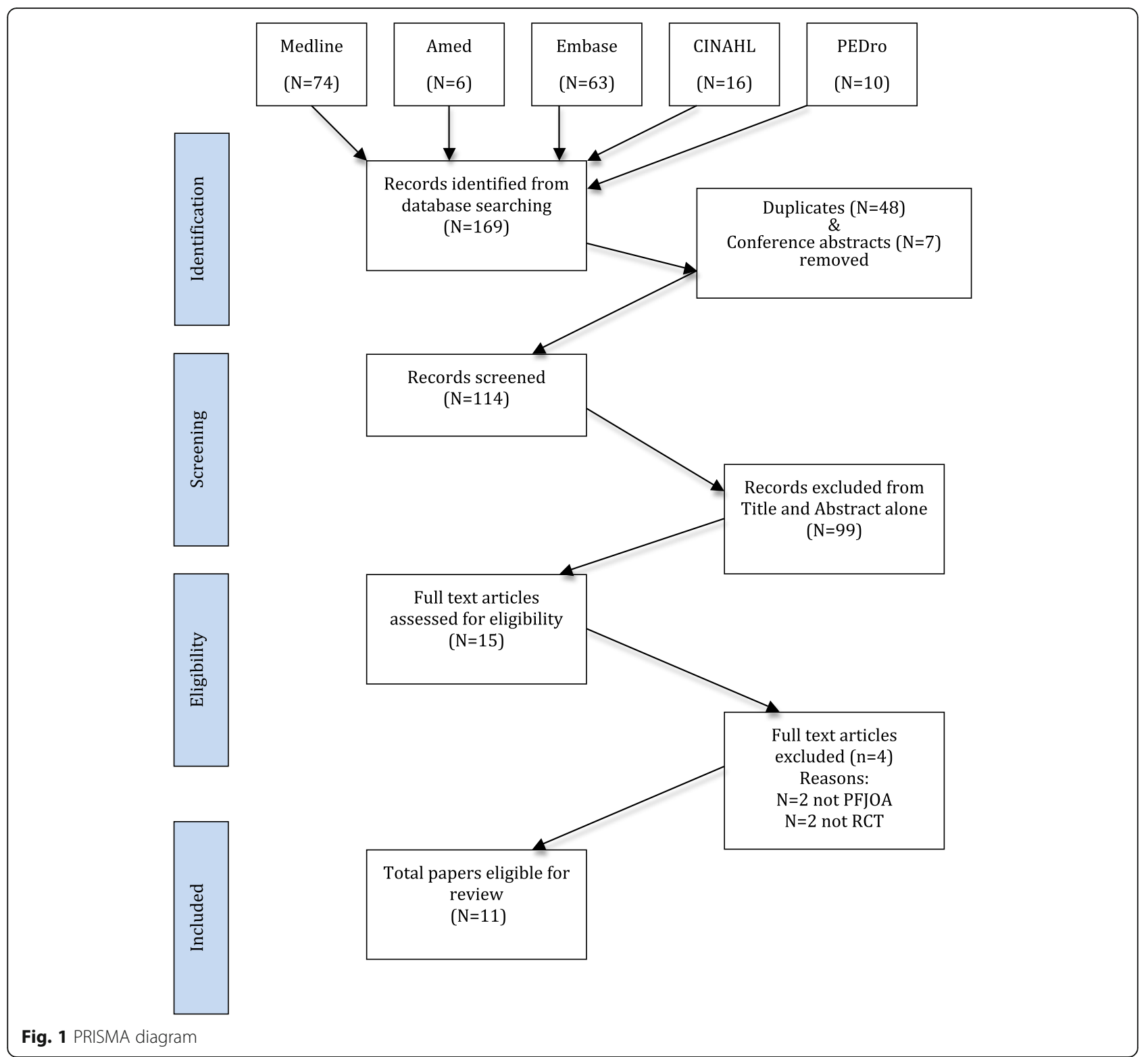

evidence of PFJOA (defined as definite joint space narrowing with osteophytosis) predominating in the lateral PFJ facet in all 12 patients with radiographic TFJOA also present in those patients. Kumar \& Ganesh [20] stated that their participants were radiologically diagnosed as patellofemoral arthritis, but provide no details of the radiographic technique used. Two studies [22, 23] used NICE clinical guidelines which stipulated that imaging was not required for a clinical diagnosis of OA. One study did not report level of symptoms [21].

All studies identified their recruitment sources. Four recruited from primary care practitioners, hospital physiotherapy departments or from patients' self-referral through adverts [13-15, 20]. Quilty et al. [21] recruited from a large established community cohort study.
Crossley et al. [17] recruited solely from primary care physiotherapy practices. Cushnaghan et al. [18] recruited from a hospital rheumatology clinic. Hunter et al. [19] and Crossley et al. [16] both stated they recruited from the community but did not provide further details. Tan et al. $[22,23]$ recruited via print media in a variety of locations such as pharmacies, community notice boards, doctors' surgeries, and allied health professionals' clinics.

\section{Randomisation and concealment}

Sealed opaque envelopes were used to randomise subjects in three studies [13-15]. Five trials used computergenerated randomisation [17, 19-23]. Two studies did not provide information that their groups were balanced at baseline with respect to the main confounding 
variables $[18,20]$. Five studies used concealed allocation; the other studies did not (Table 1).

\section{Intention-to-treat analysis}

Intention-to-treat analysis was performed in five studies. The crossover design studies $[14,15]$ had no dropouts as well as those of within subjects design [16, 18, 23]. As all participants completed these studies, a point was allocated in the PEDro score in this criterion. Communication with the lead author in the Crossley et al. [16] study clarified that all 14 participants completed their study [22]. had no dropouts after 6 weeks, but excluded 2 participants in the case-complete analysis.

\section{Blinding}

Due to the inherent nature of all the included studies, it was not possible to blind therapists to treatment allocation. Additionally, only three studies had participants blinded to the treatment groups $[17,19,22]$. In the eight other studies, blinding of the participants was not possible and it is likely they were able to distinguish between the interventions. The assessors were blinded to group allocation in seven out of the eleven studies which would mitigate against, though not exclude the possibility of bias.

\section{Interventions}

The interventions used in the trials were bracing $(\mathrm{n}=4)$, taping $(n=2)$, foot orthoses $(n=2)$, and a multimodal treatment package (which included exercises and taping) delivered by a physiotherapist $(n=3)$. Details of the included studies are outlined in Table 2.

\section{Taping interventions}

The effects of patellar taping were assessed by a trial of good quality [16] and fair quality [18]. Both had crosssectional designs studying the immediate or very shortterm effects only. Crossley et al. [16] compared 14 PFJOA patients with 14 healthy subjects. For the purpose of this review, we extracted the within-subjects' data for tape versus no-tape in the PFJOA group only, as there was no comparison between those with PFJOA and the healthy control group. The intervention was two pieces of rigid sports tape that applied pressure to direct the patellar medially and superiorly. Another two pieces of tape were applied distal to the patella to unload the infrapatellar fat pad. The tape was applied for 1-day testing only. Compared to no tape, taping significantly changed patella lateral displacement $(2.94 \% 95 \% \mathrm{CI}$ : 0.37 to $5.51, \mathrm{p}=0.028)$ and patellar lateral tilt angle $\left(-3.57^{\circ}\right.$ (95\%CI: 2.14 to $4.19, \mathrm{p}<0.001$ ). The difference between tape and no tape in mean VAS pain score immediately after performing a single-leg squat was $-15.3 \mathrm{~mm}(95 \% \mathrm{CI}$
0.4 to $30, \mathrm{p}=0.045$ ); this was a statistically and clinically meaningful decrease in pain within subjects with PFJOA.

Cushnaghan et al. [18] pulled a strip of rigid sports tape across the patellar medially and compared this to lateral directed tape and then to a piece of tape put across the patella with no directional pull (neutral). After 4 days of treatment, there was a clinically meaningful and statistically significant reduction of pain for medial directed taping compared to lateral or neutral taping (mean difference neutral $\mathrm{v}$ medial tape $=15.5(95 \% \mathrm{CI}$ 2.4 to 28.6$)$, but not for neutral $\mathrm{v}$ lateral tape $=-8(95 \%$ CI -22.5 to +6.5$)$.

\section{Bracing interventions}

Four studies assessed the effect of bracing. A randomised crossover trial [19] compared the effects of two 6week periods of brace wearing with and without a realigning patella strap in 67 participants with PFJOA. The daily average self-reported time for brace wearing for either brace was between 4.3 and $4.8 \mathrm{~h}$. There was no significant difference between brace with and without the strap in reduction in VAS pain $(0.7,95 \% \mathrm{CI}:-6.2$ to 4.8 ; $\mathrm{p}=0.81)$ nor in WOMAC pain $(-0.11,95 \% \mathrm{CI}:-0.66$ to $0.88 ; \mathrm{p}=0.77)$, stiffness $(-0.11,95 \% \mathrm{CI}:-0.53$ to 0.32 ; $\mathrm{p}=0.61)$ or function $(-0.02,95 \% \mathrm{CI}:-2.83$ to 2.79 ; $\mathrm{p}=$ $0.99)$ for the two treatment periods.

Callaghan et al. [13] performed a 6-week RCT to examine the effects of bracing versus no bracing on bone marrow lesions (BML) and pain in 126 PFJOA patients. The daily average self-reported brace wearing time was $7.4 \mathrm{~h}$. The brace group experienced a clinically and statistically significant decrease in VAS for a nominated aggravating activity $(-13 \mathrm{~mm}, 95 \% \mathrm{CI}:-20$ to $-7 ; \mathrm{p}<0.001)$ and reduction in BML volume in the PFJ compartment on magnetic resonance imaging (MRI) $-490.6 \mathrm{~mm}^{3}(95 \%$ CI: -929.5 to -51.7$)(\mathrm{p}=0.03)$. Although both trials used the same outcome after the same 6-week period of brace wearing, there was evidence of heterogeneity of the trials for the VAS $\left(I^{2}=83 \%, p=0.02\right)$. The data were pooled using a random effects model of the standardised mean difference and showed no overall statistically and clinically significant benefit on a visual analogue scale (VAS) (standardised mean difference $(\mathrm{SMD})=-0.42(95 \% \mathrm{CI}$ -1.12 to +0.29 ; Fig. 2). For the same two trials, the KOOS pain and Western Ontario and McMasters (WOMAC) were not significantly improved by bracing (SMD -0.18: 95\%CI -0.66 to 0.31; Fig. 3).

Two further studies used data from the latter trial to look at the effect of bracing on quadriceps muscle strength and inhibition [15] and patellofemoral alignment [14]. There was a significant reduction in muscle inhibition in the brace group compared to no brace at 6 weeks ( $\mathrm{n}=106$ between-group difference, -8.62\%; 95\%CI: $-13.90 \%$ to $-3.33 \%$; $\mathrm{p}=0.002$ ) with no significant 
Table 2 Summary of randomised clinical trials included in this review

\begin{tabular}{|c|c|c|c|c|c|c|c|}
\hline Author & $\begin{array}{l}\text { Type of } \\
\text { study }\end{array}$ & $\begin{array}{l}\text { Sample } \\
\text { size }\end{array}$ & Participants & Intervention & Comparator & $\begin{array}{l}\text { Outcome } \\
\text { measure }\end{array}$ & Results \\
\hline $\begin{array}{l}\text { Callaghan et al. } \\
\text { [13] }\end{array}$ & $\begin{array}{l}\text { Randomised } \\
\text { controlled } \\
\text { trial }\end{array}$ & $\begin{array}{l}n=126 \\
M=54 \\
(43 \%) \\
F=72 \\
(57 \%)\end{array}$ & $\begin{array}{l}\text { PFJ OA. } \\
\text { Mean age } 55.5 \text { years } \\
\text { (SD } 7.5 \text { ). } \\
\text { K-L score 2/3. } \\
\text { PFJ symptoms } \\
\text { (stairs/ rising from } \\
\text { chair). } \\
3 \text { months of daily } \\
\text { pain scoring }>40 / 100 \\
\text { on VAS. Painful } \\
\text { palpation of patella } \\
\text { facets. } \\
\text { BMl=31 }\end{array}$ & $\begin{array}{l}\text { Brace with or } \\
\text { without strap } \\
\text { (participants } \\
\text { preference) worn for } \\
\text { mean } 7.4 \text { hours a } \\
\text { day for } 6 \text { weeks. }\end{array}$ & No brace. & $\begin{array}{l}\text { VAS (knee pain } \\
\text { in last } 7 \text { days } \\
\text { during } \\
\text { nominated } \\
\text { activity). } \\
\text { Change in PF } \\
\text { BML. } \\
\text { Secondary: } \\
\text { KOOS-pain and } \\
\text { KOOS-ADL. }\end{array}$ & $\begin{array}{l}\text { At } 6 \text { weeks, } \\
\text { between groups } \\
\text { adjusted mean } \\
\text { differences } \\
\text { (VAS: }-1.3 \mathrm{~cm} \\
\text { (95\%Cl }-2.0 \text { to } \\
-0.7 ; \mathrm{p}<0.001 \text { ) } \\
\text { PF BML volume: } \\
-490.6 \mathrm{~mm}^{3} \text {, } \\
95 \% \mathrm{Cl}-929.5 \text { to } \\
-51.7 ; \mathrm{p}=0.03 \text { ) } \\
\text { KOOS-pain } 5.7 \\
\text { (95\% Cl: } 0.6 \\
\text { to } 10.8, \mathrm{p}=0.03 \\
\text { KOOS-ADL } 4.5, \\
(95 \% \mathrm{Cl} ; 0.5 \text { to } 8.5 \text {, } \\
\mathrm{P}=0.03 \text { ) }\end{array}$ \\
\hline $\begin{array}{l}\text { Callaghan et al. } \\
\text { [14] }\end{array}$ & $\begin{array}{l}\text { Within } \\
\text { subjects } \\
\text { crossover } \\
\text { design with } \\
\text { randomised } \\
\text { order. }\end{array}$ & $\begin{array}{l}n=30 \\
M=13 \\
(43 \%) \\
F=17 \\
(57 \%)\end{array}$ & $\begin{array}{l}\text { PFJ OA } \\
\text { Mean age } 57 \text { years } \\
\text { (SD 7.8). } \\
\text { Mean BMI } 27.8 \text { (SD } \\
4.2 \text { ) } \\
\text { K-L score } 2 / 3 \\
\text { PFJ symptoms } \\
\text { (stairs/ rising from } \\
\text { chair) } \\
3 \text { months of daily } \\
\text { pain scoring } 40 / 100 \\
\text { on VAS. Painful } \\
\text { palpation of patella } \\
\text { facets. }\end{array}$ & $\begin{array}{l}\text { Weight-bearing MRI } \\
\text { with brace. }\end{array}$ & $\begin{array}{l}\text { Weight-bearing MRI } \\
\text { with no brace. }\end{array}$ & $\begin{array}{l}\text { Patella position } \\
\text { measured on } \\
\text { MRI. }\end{array}$ & $\begin{array}{l}\text { Mean difference } \\
\text { between groups } \\
\text { Lateral PFJ } \\
\text { contact area: } \\
\left(0.94 \mathrm{~cm}^{2}, 95 \% \mathrm{Cl}\right. \\
0.07 \text { to } 1.8 \\
\mathrm{p}=0.04) \\
\text { PFJ lateral } \\
\text { distance }-0.06 \\
\mathrm{~cm} 95 \% \mathrm{Cl}-0.12 \text {, to } \\
-0.01 \\
(p=0.03) .\end{array}$ \\
\hline $\begin{array}{l}\text { Callaghan et al. } \\
\text { [15] }\end{array}$ & $\begin{array}{l}\text { Randomised } \\
\text { controlled } \\
\text { trial }\end{array}$ & $\begin{array}{l}n=108 \\
M=49 \\
(45 \%) \\
F=59 \\
(55 \%)\end{array}$ & $\begin{array}{l}\text { PFJ OA } \\
\text { Mean age } 55.5 \text { years } \\
\text { K-L score } 2 / 3 \\
\text { PFJ symptoms } \\
\text { (stairs/ rising from } \\
\text { chair) } \\
3 \text { months of daily } \\
\text { pain VAS }>40 / 100 \text {. } \\
\text { BMI }=30.7\end{array}$ & $\begin{array}{l}\text { Brace worn for } 7.4 \\
\text { hours a day on } \\
\text { average for } 6 \text { weeks. }\end{array}$ & No brace & $\begin{array}{l}\text { Isometric MVC } \\
\text { to assess } \\
\text { quadriceps } \\
\text { muscle } \\
\text { strength and } \\
\text { AMI. }\end{array}$ & $\begin{array}{l}\text { At } 6 \text { weeks: } \\
\text { between group } \\
\text { difference in MVC } \\
\text { (9.09 Nm; } 95 \% \mathrm{Cl} \text { : } \\
-4.89 \text { to } 23.07) \\
\text { between group } \\
\text { difference in AMl } \\
-8.62 \% ; 95 \% \mathrm{Cl} \text { : } \\
-13.90 \% \text { to } \\
-3.33 \%)\end{array}$ \\
\hline $\begin{array}{l}\text { Crossley et al. } \\
\text { [16] }\end{array}$ & $\begin{array}{l}\text { Within } \\
\text { subject } \\
\text { design with } \\
\text { randomised } \\
\text { order. }\end{array}$ & $\begin{array}{l}n=14 \\
M=2 \\
(14 \%) \\
F=12 \\
(86 \%)\end{array}$ & $\begin{array}{l}\text { Predominant PFJ OA. } \\
\text { Mean age } 56.9 \text { (SD } \\
\text { 7.4). } \\
\text { Mean BMI } 27.6 \text { (SD } \\
\text { 3.4). } \\
\text { Anterior knee pain } \\
\text { with stairs, squatting, } \\
\text { rising from sitting. } \\
\text { Tenderness } \\
\text { peripatellar region. } \\
\text { Radiographic } \\
\text { evidence of } \\
\text { osteophytes or } \\
\text { severity grade } \geq 2\end{array}$ & Tape & No tape & $\begin{array}{l}\text { Patella position } \\
\text { on MRI. } \\
\text { VAS (pain on } \\
\text { performing } \\
\text { single leg } \\
\text { squat x5). }\end{array}$ & $\begin{array}{l}\text { Immediate pre } \\
\text { post rape within } \\
\text { groups mean } \\
\text { differences } \\
\text { patella lateral } \\
\text { displacement } \\
\text { (2.94\% } 95 \% \mathrm{Cl} \text { : } \\
0.37 \text { to } 5.51 \mathrm{p}= \\
0.028) \\
\text { Bisect offset: } \\
0.58 \% \text { (95\%Cl: } \\
-3.35 \text { to } 4.5 \mathrm{p}= \\
0.757) \\
\text { patellar lateral tilt } \\
\text { angle: }-3.57^{0} \\
\text { (95\%Cl: } 2.14 \text { to } \\
4.19 \mathrm{p}<0.001 \text { ) } \\
\text { VAS pain: } \\
-15.3 \mathrm{~mm}, 95 \% \mathrm{Cl} \text { : } \\
0.4 \text { to } 30.3 \mathrm{p}= \\
0.045) \text {. }\end{array}$ \\
\hline $\begin{array}{l}\text { Crossley et al. } \\
\text { [17] }\end{array}$ & $\begin{array}{l}\text { Randomised } \\
\text { Controlled } \\
\text { Trial. }\end{array}$ & $\begin{array}{l}n=92 \\
M=39 \\
(42 \%)\end{array}$ & $\begin{array}{l}\text { PFJ OA. } \\
\text { Mean age: } 54.5 \text { (SD } \\
10 \text { years). }\end{array}$ & $\begin{array}{l}\text { PFJ targeted } \\
\text { programme that } \\
\text { combined exercise, }\end{array}$ & $\begin{array}{l}\text { Control group: } \\
\text { physiotherapist } \\
\text { delivered, single- }\end{array}$ & $\begin{array}{l}\text { Perceived } \\
\text { GRoC, } \\
\text { VAS pain }\end{array}$ & $\begin{array}{l}\text { At } 3 \text { months: } \\
\text { superior GRoC } \\
\text { outcomes }\end{array}$ \\
\hline
\end{tabular}


Table 2 Summary of randomised clinical trials included in this review (Continued)

\begin{tabular}{|c|c|c|c|c|c|}
\hline Author & $\begin{array}{l}\text { Type of } \\
\text { study }\end{array}$ & $\begin{array}{l}\text { Sample } \\
\text { size }\end{array}$ & Participants & Intervention & Comparator \\
\hline & & $\begin{array}{l}F=53 \\
(58 \%)\end{array}$ & $\begin{array}{l}\text { BMI: } 27.6 \\
3 / 10 \text { pain VAS during } \\
\text { PFJ loading activities } \\
\text { (using stairs/rising } \\
\text { from sitting or } \\
\text { squatting) and on } \\
\text { most days in the } \\
\text { past month. } \\
\text { Evidence of PFJ } \\
\text { osteophytes on } \\
\text { radiograph. }\end{array}$ & $\begin{array}{l}\text { education, manual } \\
\text { therapy and taping. } \\
8 \text { treatments of } 60- \\
\text { minute duration over } \\
\text { a } 12 \text {-week period. }\end{array}$ & $\begin{array}{l}\text { patient osteoarthritis } \\
\text { education. } \\
8 \text { treatments of } 60 \text { - } \\
\text { minute duration over } \\
\text { a } 12 \text {-week period + } \\
\text { home exercises }\end{array}$ \\
\hline
\end{tabular}

\begin{tabular}{|c|c|c|c|c|c|c|c|}
\hline $\begin{array}{l}\text { Cushnaghan } \\
\text { et al. [18] }\end{array}$ & $\begin{array}{l}\text { Within } \\
\text { subjects } \\
\text { crossover } \\
\text { trial with } \\
\text { randomised } \\
\text { order }\end{array}$ & $\begin{array}{l}N=14 \\
F=10 \\
M=4\end{array}$ & $\begin{array}{l}\text { Anterior knee pain } \\
\text { on walking and with } \\
\text { using } \\
\text { steps and stairs. } \\
\text { Radiographic PFJ OA } \\
\text { predominant in } \\
\text { lateral facet. } \\
\text { Concomitant TFJ OA } \\
\text { in all subjects. } \\
\text { Mean age 70.4yrs } \\
\text { (range 55-84) } \\
\text { Disease duration } \\
\text { 12.5yrs }\end{array}$ & $\begin{array}{l}\text { 1. Medial directed } \\
\text { patellar taping } \\
\text { 2. lateral directed } \\
\text { patellar taping } \\
4 \text { days for each tape } \\
\text { condition }\end{array}$ & $\begin{array}{l}\text { Neutral taping } \\
4 \text { days for each tape } \\
\text { condition }\end{array}$ & VAS knee pain & $\begin{array}{l}\text { At day } 4: \\
\text { Mean difference } \\
\text { neutral } \vee \text { medial } \\
\text { tape }=15.5 \mathrm{~mm} \\
(95 \% \mathrm{Cl} 2.4 \text { to } \\
28.6, \mathrm{p}=0.023) \\
\text { Mean difference } \\
\text { neutral } \vee \text { lateral } \\
\text { tape at day } 4= \\
-8 \mathrm{~mm}(95 \% \mathrm{Cl} \\
-22.5 \text { to } 6.5)\end{array}$ \\
\hline $\begin{array}{l}\text { Kumar \& } \\
\text { Ganesh [20] }\end{array}$ & $\begin{array}{l}\text { Randomised } \\
\text { trial }\end{array}$ & $\begin{array}{l}n=60 \\
M / F \text { not } \\
\text { stated }\end{array}$ & $\begin{array}{l}\text { Radiographic PFJ OA } \\
\text { with anterior knee } \\
\text { pain } \\
\text { VAS knee pain equal } \\
\text { and greater than } \\
3 \mathrm{~cm} \\
\text { Age not stated }\end{array}$ & $\begin{array}{l}\text { Short wave } \\
\text { diathermy }+ \text { joint } \\
\text { mobilisations }+ \\
\text { isometric exercises + } \\
\text { medial patellar } \\
\text { taping }\end{array}$ & $\begin{array}{l}\text { Short wave } \\
\text { diathermy }+ \text { joint } \\
\text { mobilisations }+ \\
\text { isometric exercises + } \\
\text { lateral patellar taping }\end{array}$ & $\begin{array}{l}\text { Knee pain VAS } \\
\text { WOMAC }\end{array}$ & $\begin{array}{l}\text { Lateral taping } \\
\text { group "highly } \\
\text { significant" } \\
\text { compared to } \\
\text { medial taping } \\
\text { group for VAS } \\
\text { and WOMAC ( }= \\
0.0001 \text { ) }\end{array}$ \\
\hline $\begin{array}{l}\text { Hunter et al. } \\
\text { [19] }\end{array}$ & $\begin{array}{l}\text { Randomised } \\
\text { crossover } \\
\text { trial }\end{array}$ & $\begin{array}{l}n=80 \\
M=17 \\
(21 \%) \\
F=63 \\
(79 \%)\end{array}$ & $\begin{array}{l}\text { Lateral PFJ OA or } \\
\text { mixed lateral PFJ } \\
\text { with concomitant } \\
\text { TFJ OA but } \\
\text { demonstrates source } \\
\text { of symptoms is PFJ } \\
\text { with anterior knee } \\
\text { symptoms on most } \\
\text { days with stair } \\
\text { climbing and/ or } \\
\text { rising from a chair } \\
\text { and patellar }\end{array}$ & $\begin{array}{l}\text { Active treatment } \\
\text { (Treatment B): } \\
\text { BioSkin Q Brace with } \\
\text { realigning T-strap for } \\
6 \text { week duration and } \\
\text { mean of } 4.8 \text { hours/ } \\
\text { day, followed by a } \\
\text { washout period ( } 6 \\
\text { weeks) and then } \\
\text { crossover to } 6 \text { weeks } \\
\text { of brace with no } \\
\text { strap (Treatment A). }\end{array}$ & $\begin{array}{l}\text { Control (Treatment } \\
\text { A): } \\
\text { BioSkin Q Brace } \\
\text { without realigning T- } \\
\text { strap for } 6 \text { week dur- } \\
\text { ation and mean of } \\
4.3 \text { hours a day, } \\
\text { followed by a wash- } \\
\text { out period ( } 6 \text { weeks) } \\
\text { followed by } 6 \text { weeks } \\
\text { of wearing a brace } \\
\text { with strap (Treatment }\end{array}$ & $\begin{array}{l}\text { Primary: VAS } \\
\text { (average pain } \\
\text { over previous } \\
\text { week). } \\
\text { Secondary: } \\
\text { WOMAC (pain, } \\
\text { function, } \\
\text { stiffness } \\
\text { subscales). }\end{array}$ & $\begin{array}{l}\text { At } 6 \text { weeks: } \\
\text { No significant } \\
\text { brace treatment } \\
\text { effect (VAS }-0.68 \text {, } \\
95 \% \text { Cl: }-6.2 \text { to } \\
4.8 p=0.81) \\
\text { No significant } \\
\text { difference } \\
\text { between the } \\
\text { groups for } \\
\text { WOMAC pain, } \\
\text { function or }\end{array}$ \\
\hline
\end{tabular}


Table 2 Summary of randomised clinical trials included in this review (Continued)

\begin{tabular}{|c|c|c|c|c|c|c|c|}
\hline Author & $\begin{array}{l}\text { Type of } \\
\text { study }\end{array}$ & $\begin{array}{l}\text { Sample } \\
\text { size }\end{array}$ & Participants & Intervention & Comparator & $\begin{array}{l}\text { Outcome } \\
\text { measure }\end{array}$ & Results \\
\hline & & & $\begin{array}{l}\text { mobilisations. } \\
\text { Mean age: } 60.5 \text { (SD } 9 \\
\text { years) } \\
\text { BMI } 27.6\end{array}$ & & B). & & $\begin{array}{l}\text { stiffness } \\
\text { subscales. }\end{array}$ \\
\hline Quilty et al. [21] & $\begin{array}{l}\text { Randomised } \\
\text { controlled } \\
\text { trial }\end{array}$ & $\begin{array}{l}n=87 \\
M / F \text { not } \\
\text { stated }\end{array}$ & $\begin{array}{l}\text { Chronic knee pain } \\
\text { with predominant } \\
\text { PFJ OA on } \\
\text { radiographs (PFJ } \\
\text { Osteophytes). } \\
\text { Mean age: } 66.8 \text { years } \\
\text { (SD 9.5) } \\
\text { BMl:30 }\end{array}$ & $\begin{array}{l}\text { Physiotherapy } \\
\text { delivered treatments } \\
\text { (exercises, patellar } \\
\text { taping, footwear and } \\
\text { postural advice). } \\
9 \times \text { sessions, } 30- \\
\text { minute duration over } \\
10 \text { weeks. }\end{array}$ & $\begin{array}{l}\text { Control (no } \\
\text { treatment) }\end{array}$ & $\begin{array}{l}\text { Primary: VAS } \\
\text { (overall pain } \\
\text { during past } \\
\text { month). } \\
\text { WOMAC } \\
\text { function sub- } \\
\text { score. } \\
\text { Secondary: } \\
\text { MVC to assess } \\
\text { quadriceps } \\
\text { strength. }\end{array}$ & $\begin{array}{l}\text { At } 5 \text { months: } \\
\text { adjusted between } \\
\text { means } \\
\text { differences: } \\
\text { VAS }-6.4 \mathrm{~mm} \text { (95\% } \\
\text { Cl: }-15.3 \text { to } 2.4) \\
\text { WOMAC }-0.6 \\
\text { (95\% Cl: }-3.7 \text { to } \\
2.4) \\
\text { no significant } \\
\text { differences } \\
\text { between groups } \\
\text { at } 12 \text { months } \\
\text { quadriceps } \\
\text { muscle strength } \\
\text { at } 5 \text { months } \\
11.7 N m \text { ( } 95 \% \text { Cl: } \\
4.5 \text { to } 19 ; p= \\
0.002 \text { ) } \\
\text { but not } 12 \\
\text { months ( } p=0.08 \text { ). }\end{array}$ \\
\hline Tan et al. [22] & $\begin{array}{l}\text { Randomised } \\
\text { controlled } \\
\text { trial }\end{array}$ & $\begin{array}{l}N=26 \\
F 16\end{array}$ & $\begin{array}{l}\text { Clinical diagnosis of } \\
\text { PFJ OA based on } \\
\text { NICE guidelines. } \\
\text { Mean age } 60 \\
\text { (SD8)yrs }\end{array}$ & $\begin{array}{l}\text { Commercially } \\
\text { available foot } \\
\text { orthotics } \\
6 \text { weeks continuous } \\
\text { wear }\end{array}$ & $\begin{array}{l}\text { Sham foot orthotic } \\
\text { inserts } \\
6 \text { weeks continuous } \\
\text { wear }\end{array}$ & $\begin{array}{l}\text { Primary: } \\
\text { feasibility of } \\
\text { full RCT } \\
\text { Secondary } \\
\text { KOOS } \\
\text { AKPS } \\
\text { VAS } \\
\text { GROC }\end{array}$ & $\begin{array}{l}\text { Adjusted mean } \\
\text { difference } \\
\text { (95\% CI) } 6 \text { weeks: } \\
\text { KOOS pain: } 8.1 \\
\text { (-6.9 to 23.1) } \\
\text { KOOS symptoms: } \\
4.4 \text { (-6.6 to 15.5) } \\
\text { KOOS ADL: } 13.7 \\
\text { (0.2 to 27.2) } \\
\text { KOOS Sport: } 25.7 \\
\text { (-1.7 to 53) } \\
\text { KOOSQoL: } 11.3 \\
\text { (-1.4 to 24) } \\
\text { AKPS: } 9.1 \\
\text { (- } 8.6 \text { to } 26.8) \\
\text { VAS most } \\
\text { aggravating } \\
\text { activity: } 21.9 \mathrm{~mm} \\
\text { (2.1 to 46.0) } \\
\text { Average VAS on } \\
\text { most aggravating } \\
\text { activity: } 15.8 \mathrm{~mm} \\
(-4.9 \text { to } 36.6) \\
\text { GRoC foot } \\
\text { orthoses group: } \\
\text { median value } \\
\text { 2.5(min= }-1 ; \text { max } \\
=6 \text { ) } \\
\text { GRoC sham } \\
\text { group: median } \\
\text { value } 3 \text { (min=0; } \\
\text { max= 6) }\end{array}$ \\
\hline Tan et al. [23] & $\begin{array}{l}\text { within- } \\
\text { subject, } \\
\text { cross-over } \\
\text { design with } \\
\text { randomised } \\
\text { order }\end{array}$ & $\begin{array}{l}N=21 \\
F=14\end{array}$ & $\begin{array}{l}\text { Clinical diagnosis of } \\
\text { PFJ OA based on } \\
\text { NICE guidelines } \\
\text { mean age } 58 \text { (SD8) } \\
\text { yrs } \\
\text { BMI } 27.0 \text { (SD 4.8) }\end{array}$ & $\begin{array}{l}\text { Commercially } \\
\text { available foot } \\
\text { orthotic }\end{array}$ & Sham inserts & $\begin{array}{l}\text { Primary } \\
\text { outcome: } \\
\text { biomechanical } \\
\text { motion effects } \\
\text { Secondary } \\
\text { outcome VAS } \\
\text { pain }\end{array}$ & $\begin{array}{l}\text { No significant } \\
\text { immediate effects } \\
\text { of foot orthotics } \\
\text { compared to } \\
\text { sham inserts on } \\
\text { VAS pain scores } \\
\text { VAS mean } \\
\text { differences } 95 \%\end{array}$ \\
\hline
\end{tabular}


Table 2 Summary of randomised clinical trials included in this review (Continued)

\begin{tabular}{|c|c|c|c|c|c|c|c|}
\hline Author & $\begin{array}{l}\text { Type of } \\
\text { study }\end{array}$ & $\begin{array}{l}\text { Sample } \\
\text { size }\end{array}$ & Participants & Intervention & Comparator & $\begin{array}{l}\text { Outcome } \\
\text { measure }\end{array}$ & Results \\
\hline & & & & & & & $\begin{array}{l}\text { Level walking } 4.2 \\
(-2.9,11.2) \\
\text { Stair ascent }-3.4 \\
(-13.1 \text { to } 6.3) \\
\text { Stair descent } 0.7 \\
(-11.5 \text { to } 12.9)\end{array}$ \\
\hline
\end{tabular}

Abbreviations: $A M I$ arthrogenous muscle inhibition, $M R I$ magnetic resonance imaging, $O A$ osteoarthritis, $P F J$ patellofemoral joint, $B M I$ body mass index, $M V C$ maximum voluntary contraction, $G R O C$ perceived global rating of change, $S D$ standard deviation, $K-L$ Kellgren-Lawrence, VAS visual analogue scale, $K O O S$-(ADL) knee injury and osteoarthritis outcome score (Activities of Daily Living), WOMAC Western Ontario and McMaster Universities Osteoarthritis Index, M males, $F$ females, KOOS QoL knee injury and osteoarthritis outcome score (Quality of Life), NICE National Institute for Clinical Excellence

change in quadriceps strength [15]. A further 30 patients from the same cohort were randomised to brace and no brace to assess the effect on structural patellofemoral parameters, using weight bearing MRIs to assess patellar position and patellofemoral alignment [14]. The application of a brace compared to no brace significantly increased PFJ lateral contact area ( $\mathrm{n}=30$ within subjects difference $0.94 \mathrm{~cm}^{2} 95 \%$ CI 0.07 to $1.81, \mathrm{p}=0.04$ ) and reduced PFJ lateral distance on weight bearing MRI ( $\mathrm{n}=$ 30 within subjects difference $0.06 \mathrm{~cm} 95 \%$ CI 0.12 to $0.01, \mathrm{p}=0.03$ ) which was assumed to reduce patellofemoral contact stresses.

\section{Foot orthotics interventions}

Two good quality studies by the same research group examined the effects of foot orthotics on painful PFJOA. A RCT [22] compared a commercially available foot orthotic to a flat insert sham. The purpose of this trial was to provide feasibility information on sample size, recruitment for a full scale trial. The active intervention orthotic fitted inside the shoes had a $6^{\circ}$ varus wedge with a medial arch support. After 6 weeks both groups reported improvements in pain and function. The foot orthotic group demonstrated a greater but nonsignificant improvement in mean change in maximum and average pain severity on a VAS during the most aggravating activity (of either 'rising from sitting', 'stair ambulation', or 'squatting') in the previous week (maximum VAS $21.9 \mathrm{~mm}$ (95\%CI: -2.1 to 46.0 ); average VAS $15.8 \mathrm{~mm}$ (95\% CI -4.9 to 36.6$)$ ). Although not statistically significant, the between groups VAS scores exceeded the minimal clinically important difference for chronic musculoskeletal pain. The Knee injury and
Osteoarthritis Outcome Score - activities of daily living (KOOS-ADL) subscale was significantly improved in the foot orthotic group compared to the sham group (13.7; 95\% CI 0.2 to 27.2). There were no significant between groups adjusted mean differences in the other KOOS subscales (Table 2) including KOOS pain $(8.1 ; 95 \% \mathrm{CI}$ : -6.9 to 23.1). The second good quality trial [23] compared the immediate effects of foot orthotics and flat sham inserts on lower limb biomechanics, knee pain and confidence in individuals with PFJOA. For the immediate effect on VAS knee pain, there were no statistically or clinically significant differences between the foot orthotic and the sham insert during level walking (4.2mm, 95\% CI -2.9 to 11.2), during stair ascent $(-3.4 \mathrm{~mm}, 95 \% \mathrm{CI}-13.1$ to 6.3$)$ or during stair descent (0.7mm, 95\% CI -11.5 to 12.9$)$.

\section{Multimodal physiotherapy interventions}

Three RCTs studied the effects of multimodal treatment programmes delivered by physiotherapists in patients with PFJOA. The study quality ranges from good [17, 21] to poor [20]. Quilty et al. [21] compared the effect on pain and function of a combination of exercises, patella taping, posture and footwear advice (9 sessions, 30min duration over 10 weeks) with a control group. Those randomised to the control group were not informed that they were in a trial. At the baseline visit, patients in both the intervention and control groups had a half-hour discussion with a physiotherapist concerning diagnosis, prognosis, footwear, weight reduction and activity. General exercise was encouraged but no specific quadriceps exercises were advised. Kumar and Ganesh [20] gave all participants the electrical therapy modality

\begin{tabular}{|c|c|c|c|c|c|c|c|c|c|c|}
\hline \multirow{3}{*}{$\begin{array}{l}\text { Study or Subgroup } \\
\text { Callaghan } 2015\end{array}$} & \multicolumn{3}{|c|}{ Brace } & \multicolumn{3}{|c|}{ Control } & \multicolumn{2}{|r|}{ Std. Mean Difference } & \multirow{2}{*}{\multicolumn{2}{|c|}{$\begin{array}{l}\text { Std. Mean Difference } \\
\text { IV, Random, } 95 \% \mathrm{Cl}\end{array}$}} \\
\hline & Mean & SD & Total & Mean & SD & Total & Weight & IV, Random, 95\% Cl & & \\
\hline & 5 & 1.6 & 56 & 6.3 & 1.75 & 61 & $51.3 \%$ & $-0.77[-1.15,-0.39]$ & & \\
\hline Hunter 2011 & 0.1 & 12.5 & 41 & 0.68 & 12.4 & 39 & $48.7 \%$ & $-0.05[-0.48,0.39]$ & & \\
\hline Total $(95 \% \mathrm{CI})$ & & & 97 & & & 100 & $100.0 \%$ & $-0.42[-1.12,0.29]$ & & \\
\hline \multicolumn{9}{|c|}{$\begin{array}{l}\text { Heterogeneity: } \mathrm{Tau}^{2}=0.22 ; \mathrm{Chi}^{2}=6.01, \mathrm{df}=1(\mathrm{P}=0.01) ; \mathrm{I}^{2}=83 \% \\
\text { Test for overall effect: } \mathrm{Z}=1.15(\mathrm{P}=0.25)\end{array}$} & $\begin{array}{ll}1 & 1 \\
-1 & -0.5 \\
\text { Favours Brace }\end{array}$ & $\begin{array}{ccc}1 & 1 \\
0 & 0.5 & 1 \\
\text { Favours [control] }\end{array}$ \\
\hline
\end{tabular}




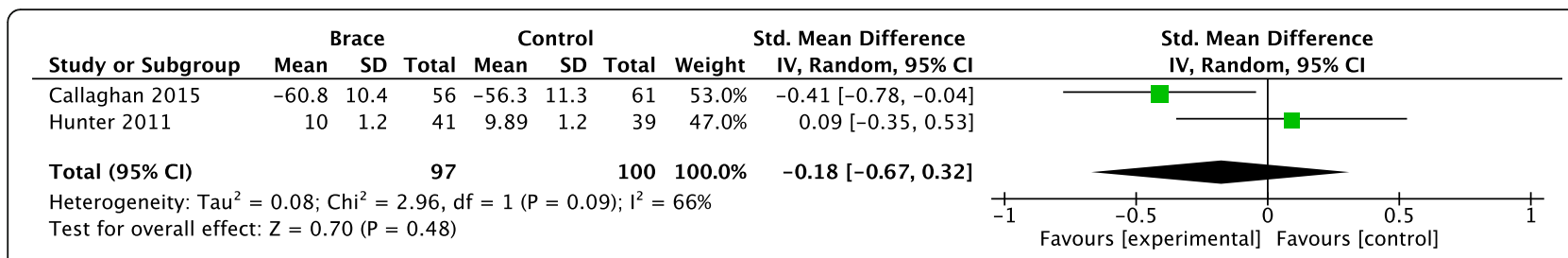

Fig. 3 KOOS PAIN/WOMAC pain brace trials versus controls

of short wave diathermy, combined with joint mobilisations and isometric exercises. One group was randomly assigned to medial patellar taping and the second group to lateral patellar taping. The shortwave diathermy was applied for 20 min daily, but further details of the settings are not provided. The isometric exercises were to the quadriceps in supine, maintained for $6 \mathrm{~s}$ and repeated for 10 times with $10 \mathrm{~s}$ rest between each repetition. The taping technique was described as displacing the patella medially or laterally using manual pressure and then maintained in this position by tape across the middle of the patella using light to moderate pressure. Data for the taping intervention could not be extracted for separate analysis. Crossley et al. [17] compared combined exercises, patella taping, manual therapy and education with a control group of education only singlepatient sessions, designed to control for the patient therapist interaction and psychosocial contact inherent with the PFJ-specific combined physiotherapy treatment $(8$ sessions, 60-min duration over 12 weeks).

Quilty et al. [21] found no significant between groups difference in disability on the WOMAC function subscale after 5 months. Kumar and Ganesh [20] described the analysis for WOMAC between group A and group B after 9 months as highly significant $(\mathrm{p}=$ 0.0001 ), but did not provide any further details such as means and variance. There was no reference to the clinical significance of the outcome. Crossley et al. [17] noted no significant between groups improvement in the KOOS-ADL.

Quilty et al. [21] found no statistically or clinically significant reduction in average 'pain during the previous month' (VAS -6.4mm) at 5 months. Crossley et al. [17] recorded a clinically meaningful and significant between groups mean reduction in 'pain during an aggravating activity' (VAS $-15.2 \mathrm{~mm}$ ) at 3 months.

Pooling the data from the two good quality trials which used taping, with a random effects standardised mean difference, there appeared to be evidence of a small overall beneficial effect of the intervention for the VAS (-0.41 95\%CI: -0.71 to -0.09 ; Fig. 4$)$.

\section{Discussion}

Overall this systematic review found good quality evidence that a combined physiotherapy approach may cause a reduction in patellofemoral pain. It is clear that more robust trials are needed to better define the role of these therapies as well as bracing, taping and foot orthotics in the management of symptomatic PFJOA. The consistent flaws in the good quality trials were the lack of blinding of the therapists in all the trials and the lack of blinding of the participants in all but two trials.

A greater number of participants in the reviewed trials were women. This is consistent with data concerning the frequency of PFJOA in the general population. There are no standardised clinical methods used to diagnose PFJOA [29]. Nine studies used a combination of subjective and objective information and radiographic evidence of PFJOA to make the diagnosis. Two based their assessments on NICE clinical guidelines which stipulated that imaging was not required for a clinical diagnosis of OA.

Nine studies used pain on stair climbing and rising from a chair as a subjective criterion and four studies also included pain on a squatting manoeuvre. Tan et al. $[22,23]$ used NICE clinical guidelines which included the criteria of anterior knee pain greater than $30 / 100 \mathrm{~cm}$ on the VAS during stair ambulation, sitting or squatting. These activities are known to load the PFJ and to be

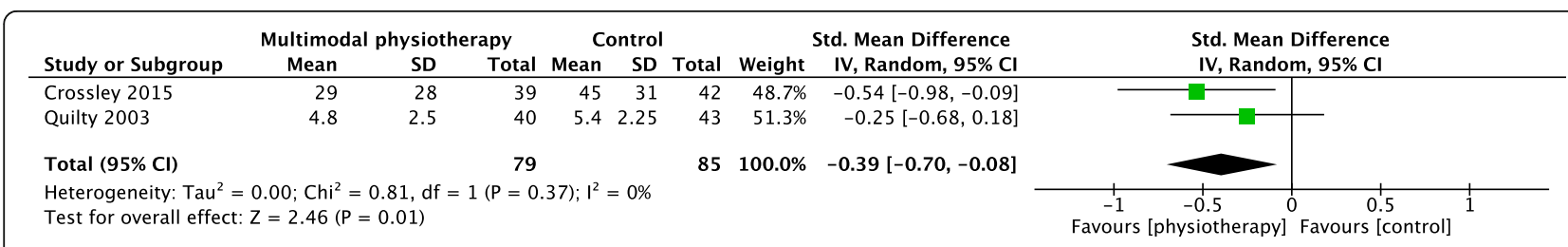

Fig. 4 VAS multimodal physiotherapy versus controls 
painful activities in PFJOA. Quilty et al. [21] did not use any specific subjective indicators commonly used to diagnose PFJOA. Their participants were identified by chronic knee pain and radiographic evidence of PFJOA. Pain reproduced when palpating the patella facets was used as an objective assessment of PFJOA in 4 of the studies [13-16]. Although not validated as a diagnostic test there is general consensus within the literature that this technique is useful in characterising PFJOA $[29,30]$.

Using the same outcome measure allows comparison of a treatment modality's effectiveness across the different trials. Although a pain VAS was used in 9 out of the 11 studies, each study recorded the pain score differently, namely performing a single leg squat [16], during an aggravating activity [17, 22], average pain in past week [19], average pain during the past month [21] and average pain during a patient nominated aggravating activity [13]. Additionally, studies had different time points for assessment.

Four good quality studies examined the effect of bracing in participants with PFJOA, though three of these were based on data from a single trial. All these four studies used the Bioskin Q brace which means the results are only applicable to this specific brace and cannot be generalised to all knee braces. Hunter et al. [19] found no significant treatment differences between wearing a brace with a strap compared to a group wearing a brace without a strap for an average of over 4 and less than $5 \mathrm{~h}$ a day. Participant preference dictated whether the patella strap was used. Conversely, Callaghan et al. [13] noted a clinically and statistically significant reduction in pain after wearing a brace compared to a no-brace control group for an average of $7.4 \mathrm{~h}$ daily for 6 weeks. The difference in daily time wearing the brace and the absence of a no-brace control group in Hunter et al. [19], and the different VAS questions used in the studies may potentially explain these two trials' differing results.

Patellar taping is a well-established intervention for non-arthritic patellofemoral pain (PFP) or anterior knee pain [31]. It is inexpensive, and after instruction by a clinician, is self-applied by patients. Its mechanism is still unclear, but reviews have reported its pain reducing effects in PFP [32-34]. Cushnaghan et al. [18] were the first to study taping for PFJOA in their small $(n=14)$ crossover trial of three different forms of patellar taping. Since then, there has been only one other study [16] of 14 participants on efficacy of taping for PFJOA. This good quality study found a significant immediate reduction in pain on the VAS $(-15.3 \mathrm{~mm})$. As taping is known to loosen over time, it is unknown whether this effect would continue in the medium or longer term. The two good quality multimodal intervention studies delivered by physiotherapists $[16,21]$ included a patellar taping component but due to the combined approach the isolated effects of the taping modality cannot be extrapolated. Further, high-quality studies assessing longer-term effects of taping are required.

Owing to the multi-factorial nature of painful PFJOA, a combination of treatment modalities is often selected to address the different dimensions of pain and dysfunction. Overall, there was evidence of a reduction in pain among those randomised to a multimodal intervention but no significant improvement in self-reported physical function at 3 months [21] and at 5 months [17]. However, it is unclear whether participants had continued with their exercise programme once the treatment sessions had ceased and this may explain the lack of improvement in the long-term results. Additionally, Crossley et al. [17] had a high dropout rate of $21 \%$ at the 9-month follow-up.

The results of the review highlight the lack of standardisation in clinical trials of PFJOA. In order to advance our understanding of treatment response in this area, clinical markers and objective tests to diagnose PFJOA should be standardised. Additionally, there should be a consensus on the tool used to score PFJOA on radiographs. Due to the multi-factorial nature of PFJOA, further research is required to examine the effect of targeted physiotherapy interventions and where possible, methodologies and outcome measures should be standardised. The same validated outcome measures should be used across these clinical trials in order to allow comparisons of the treatment modalities. Long-term effects should also be examined.

\section{Limitations}

There were some limitations to our review. The eleven randomised clinical trials were of poor, moderate and good quality for taping, bracing and foot orthotics. There were none of excellent quality. One major limitation in all the trials was the lack of blinding of the therapists delivering the treatment, and only three trials were able to blind the participants to treatment allocation. In the eight other studies, it is likely participants were able to distinguish between the interventions. The assessors were blinded to group allocation in seven out of the eleven studies which would mitigate against, though not exclude the possibility of bias. The included papers were in the English language only; therefore, studies published in other languages may have been missed. This review has not been registered online.

\section{Conclusion}

There was a relative paucity of trials studying the effect of a biomechanical device therapy in patients with symptomatic PFJOA. There is some good quality evidence that a combined physiotherapy approach significantly 
reduces short-term pain in those with PFJOA. Longterm effects of all interventions are still unknown, which indicates the need for further research to determine the longer term impact of all biomechanical devices on outcomes in symptomatic PFJOA.

\section{Abbreviations}

AMI: Arthrogenous muscle inhibition; MRI: Magnetic resonance imaging; PFJOA: Patellofemoral joint osteoarthritis; OA: Osteoarthritis;

PFJ: Patellofemoral joint; BMI: Body mass index; MVC: Maximum voluntary contraction; GRoC: Perceived global rating of change; SD: Standard deviation; K-L: Kellgren-Lawrence; VAS: Visual analogue scale; KOOS-(ADL): Knee injury and osteoarthritis outcome score (Activities of Daily Living); WOMAC: Western Ontario and McMaster Universities Osteoarthritis Index; M: Males; F: Females; KOOS QoL: Knee injury and osteoarthritis outcome score (Quality of Life); NICE: National Institute for Clinical Excellence

\section{Supplementary information}

The online version contains supplementary material available at https://doi. org/10.1186/s13643-021-01708-3.

Additional file 1:. MEDLINE search strategy - October 2020

\section{Acknowledgements}

We would like to thanks Versus Arthritis for their support with funding for the study (grant number 21755). The research was supported also by the NIHR Manchester Biomedical Research Centre.

We also wish to thank Dr. Matthew Parkes for his advice on the metaanalysis.

\section{Authors' contributions}

MJC and EP conceived the review and acquired the data. MJC, EP and TON performed the analysis, interpretation of the data. MJC, EP and TON drafted the work and substantively revised it. MJC, EP and TON have approved the submitted version (and any substantially modified version). MJC, EP and TON agree to be personally accountable for their own contributions and to ensure that questions related to the accuracy or integrity of any part of the work. The authors read and approved the final manuscript.

\section{Funding}

This review was unfunded.

\section{Availability of data and materials}

Data are available from the corresponding author on reasonable request.

\section{Declaration}

Ethics approval and consent to participate

Not applicable

\section{Consent for publication}

Not applicable

\section{Competing interests}

The author declares that he/she has no competing interests

\section{Author details}

${ }^{1}$ Faculty of Health and Education, Department of Health Professions, Manchester Metropolitan University, Manchester, UK. ${ }^{2}$ Manchester University NHS Foundation Trust, Manchester, UK. ${ }^{3}$ Centre for Epidemiology Versus Arthritis, Faculty of Biology, Medicine and Health, Manchester Academic Health Science Centre, The University of Manchester, Manchester, UK. ${ }^{4}$ Therapies Department, Aintree University Hospital, Liverpool, UK. ${ }^{5} \mathrm{NIHR}$ Manchester Biomedical Research Centre, Manchester Academic Health Sciences Centre, Manchester University NHS Foundation Trust, Manchester, UK. ${ }^{6}$ Department of Rheumatology, Salford Royal NHS Foundation Trust, Manchester, UK.
Received: 2 March 2020 Accepted: 18 May 2021

Published online: 09 June 2021

\section{References}

1. HART HF, STEFANIK JJ, WYNDOW N, MACHOTKA Z, CROSSLEY KM. The prevalence of radiographic and MRI-defined patellofemoral osteoarthritis and structural pathology: a systematic review and meta-analysis. British Journal of Sports Medicine. 2017;51(16):1195-208. https://doi.org/10.1136/ bjsports-2017-097515.

2. CROSSLEY KM, HINMAN RS. The patellofemoral joint: the forgotten joint in knee osteoarthritis. Osteoarthritis and Cartilage. 2011;19(7):765-7. https://doi. org/10.1016/j.joca.2011.05.005.

3. MILLS K, HUNTER DJ. Patellofemoral joint osteoarthritis: an individualised pathomechanical approach to management. Best.Pract.Res.Clin.Rheumatol. 2014;28(1):73-91. https://doi.org/10.1016/j.berh.2014.01.006

4. POWERS CM, WARD SR, CHAN L-D, CHEN Y-J, TERK MR. The effect of bracing on patella alignment and patellofemoral joint contact area. Medicine and Science in Sport and Exercise. 2004;36(7):1226-32. https://doi. org/10.1249/01.MSS.0000132376.50984.27.

5. MCWALTER EJ, HUNTER DJ, HARVEY WF, MCCREE P, HIRKO KA, FELSON DT, et al. The effect of a patellar brace on three-dimensional patellar kinematics in patients with lateral patellofemoral osteoarthritis. Osteoarthritis and Cartilage. 2011;19(7):801-8. https://doi.org/10.1016/j.joca.2011.03.003.

6. FERNANDES L, HAGEN KB, BIJLSMA JWJ, ANDREASSEN O, CHRISTENSEN P, CONAGHAN PG, et al. EULAR recommendations for the nonpharmacological core management of hip and knee osteoarthritis. Annals of the Rheumatic Diseases. 2013;72(7):1125-35. https://doi.org/10.1136/a nnrheumdis-2012-202745.

7. HOCHBERG MC, ALTMAN RD, APRIL KT, BENKHALTI M, GUYATT G, MCGOWAN J, et al. American College of Rheumatology 2012 recommendations for the use of nonpharmacologic and pharmacologic therapies in osteoarthritis of the hand, hip, and knee. Arthritis Care \& Research. 2012;64(4):465-74. https://doi.org/10.1002/acr.21596.

8. NICE. 2014. Osteoarthritis: care and management [Online]. https://www.nice. org.uk/guidance/cg177/resources/osteoarthritis-care-and-management-pdf-3 5109757272517. [.

9. ZHANG W, MOSKOWITZ RW, NUKI G, ABRAMSON S, ALTMAN RD, ARDEN N, et al. OARSI recommendations for the management of hip and knee osteoarthritis, Part II: OARSI evidence-based, expert consensus guidelines. Osteoarthritis Cartilage. 2008;16(2):137-62. https://doi.org/10.1016/j.joca.2 007.12.013.

10. DUNCAN R, PEAT G, THOMAS E, WOOD L, HAY E, CROFT P. Does isolated patellofemoral osteoarthritis matter? Osteoarthritis and Cartilage. 2009;17(9): 1151-5. https://doi.org/10.1016/j.joca.2009.03.016.

11. VAN MIDDELKOOP M, BENNELL KL, CALLAGHAN MJ, COLLINS NJ, CONAGHAN PG, CROSSLEY KM, et al. International patellofemoral osteoarthritis consortium: consensus statement on the diagnosis, burden, outcome measures, prognosis, risk factors and treatment. Seminars in Arthritis and Rheumatism. 2018;47(5):666-75. https://doi.org/10.1016/j.sema rthrit.2017.09.009.

12. MAHER CG, SHERRINGTON C, HERBERT RD, MOSELEY AM, ELKINS M Reliability of the PEDro scale for rating quality of randomized controlled trials. Phys Ther. 2003;83(8):713-21. https://doi.org/10.1093/ptj/83.8.713.

13. CALLAGHAN MJ, PARKES MJ, HUTCHINSON CE, GAIT AD, FORSYTHE LM, MARJANOVIC EJ, et al. A randomised trial of a brace for patellofemoral osteoarthritis targeting knee pain and bone marrow lesions. Annals Of The Rheumatic Diseases. 2015;74(6):1164-70. https://doi.org/10.1136/a nnrheumdis-2014-206376.

14. CALLAGHAN MJ, GUNEY H, REEVES ND, BAILEY D, DOSLIKOVA K, MAGANAR $S C N$, et al. A knee brace alters patella position in patellofemoral osteoarthritis: a study using weight bearing magnetic resonance imaging. Osteoarthritis Cartilage. 2016a;24(12):2055-60. https://doi.org/10.1016/j.joca.2 016.07.003.

15. CALLAGHAN MJ, PARKES MJ, FELSON DT. The effect of knee braces on quadriceps strength and inhibition in subjects with patellofemoral osteoarthritis. Journal of Orthopaedic and Sports Physical Therapy. 2016b; 46(1):19-25. https://doi.org/10.2519/jospt.2016.5093.

16. CROSSLEY KM, MARINO GP, MACILQUHAM MD, SCHACHE AG, HINMAN RS. Can patellar tape reduce the patellar malalignment and pain associated with patellofemoral osteoarthritis? Arthritis Care and Research. 2009:61(12): 1719-25. https://doi.org/10.1002/art.24872. 
17. CROSSLEY KM, VICENZINO B, LENTZOS J, SCHACHE AG, PANDY MG, OZTURK $\mathrm{H}$, et al. Exercise, education, manual-therapy and taping compared to education for patellofemoral osteoarthritis: a blinded, randomised clinical trial. Osteoarthritis Cartilage. 2015;23(9):1457-64. https://doi.org/10.1016/j. joca.2015.04.024

18. CUSHNAGHAN J, MCCARTHY C, DIEPPE P. Taping the patella medially: a new treatment for osteoarthritis of the knee. British Medical Journal. 1994; 308(6931):753-5. https://doi.org/10.1136/bmj.308.6931.753.

19. HUNTER DJ, HARVEY W, GROSS KD, FELSON D, MCCREE P, LI, L., HIRKO, K., ZHANG, B. \& BENNELL, K. A randomized trial of patellofemoral bracing for treatment of patellofemoral osteoarthritis. Osteoarthritis and Cartilage. 2011; 19(7):792-800. https://doi.org/10.1016/j.joca.2010.12.010.

20. KUMAR A, GANESH BR. Combined effectiveness of Maitland's mobilization and patellar taping in patellofemoral osteoarthritis: Arandomised clinical trial. Indian J Physiother Occup Ther. 2011;5:14

21. QUILTY B, TUCKER M, CAMPBELL R, DIEPPE P. Physiotherapy, including quadriceps exercises and patellar taping, for knee osteoarthritis with predominant patello-femoral joint involvement: randomized controlled trial. Journal of Rheumatology. 2003;30:1311-7.

22. TAN JM, MENZ HB, CROSSLEY KM, MUNTEANU SE, HART HF, MIDDLETON KJ, et al. The efficacy of foot orthoses in individuals with patellofemoral osteoarthritis: a randomised feasibility trial. Pilot Feasibility Stud. 2019;5(1):90. https://doi.org/10.1186/s40814-019-0469-7.

23. TAN JM, MIDDLETON KJ, HART HF, MENZ HB, CROSSLEY KM, MUNTEANU SE, et al. Immediate effects of foot orthoses on lower limb biomechanics, pain, and confidence in individuals with patellofemoral osteoarthritis. Gait Posture. 2020;76:51-7. https://doi.org/10.1016/j.gaitpost.2019.10.019.

24. Higgins, J. P. T. 2008. The Cochrane Collaboration. Cochrane handbook for systematic reviews of interventions, ISBN: 978-0-470-69951-5.

25. Yu SP, Williams M, Eyles JP, Chen JS, Makovey J, Hunter DJ. Effectiveness of knee bracing in osteoarthritis: pragmatic trial in a multidisciplinary clinic. International Journal of Rheumatic Diseases. 2015;19(3):279-86.

26. HART HF, CROSSLEY KM, BONACCI J, ACKLAND DC, PANDY MG, COLLINS NJ. Immediate effects of foot orthoses on gait biomechanics in individuals with persistent patellofemoral pain. Gait \& Posture. 2020;77:20-8. https://doi. org/10.1016/j.gaitpost.2019.12.012.

27. DAMMERER D, GIESINGER JM, BIEDERMANN R, HAID C, KRISMER M, LIEBENSTEINER M. Effect of knee brace type on braking response time during automobile driving. Arthroscopy: The Journal of Arthroscopic \& Related Surgery. 2015;31(3):404-9. https://doi.org/10.1016/j.arthro.2014.09.003.

28. HINMAN RS, CROSSLEY KM, MCCONNELL J, BENNELL KL. Efficacy of knee tape in the management of osteoarthritis of the knee: blinded randomised controlled trial. British Medical Journal. 2003;327(7407):135-0. https://doi. org/10.1136/bmj.327.7407.135.

29. PEAT G, DUNCAN RC, WOOD LR, THOMAS E, MULLER S. Clinical features of symptomatic patellofemoral joint osteoarthritis. Arthritis Research and Therapy. 2012;14(2):R63. https://doi.org/10.1186/ar3779.

30. HINMAN RS, CROSSLEY KM. Patellofemoral joint osteoarthritis: an important subgroup of knee osteoarthritis. Rheumatology. 2007;46(7):1057-62. https:// doi.org/10.1093/rheumatology/kem114.

31. MCCONNELL J. The management of chondromalacia patellae: a long term solution. Australian Journal of Physiotherapy. 1986;32(4):215-23. https://doi. org/10.1016/S0004-9514(14)60654-1.

32. BARTON C, BALACHANDAR V, LACK S, MORRISSEY D. Patellar taping for patellofemoral pain: a systematic review and meta-analysis to evaluate clinical outcomes and biomechanical mechanisms. British Journal of Sports Medicine. 2013.

33. CALLAGHAN MJ, SELFE J. Patellar taping for patellofemoral pain syndrome in adults. Cochrane.Database.Syst.Rev. 2012;4:CD006717.

34. Warden SJ, Hinman RS, Watson MA Jr, Avin KG, Bialocerkowski AE, Crossley KM. Patellar taping and bracing for the treatment of chronic knee pain: a systematic review and meta-analysis. Arthritis \& Rheumatism. 2007;59:73-83.

\section{Publisher's Note}

Springer Nature remains neutral with regard to jurisdictional claims in published maps and institutional affiliations.

\section{Ready to submit your research? Choose BMC and benefit from:}

- fast, convenient online submission

- thorough peer review by experienced researchers in your field

- rapid publication on acceptance

- support for research data, including large and complex data types

- gold Open Access which fosters wider collaboration and increased citations

- maximum visibility for your research: over $100 \mathrm{M}$ website views per year

At BMC, research is always in progress.

Learn more biomedcentral.com/submissions 